\title{
PERILAKU MALAS BELAJAR MAHASISWA DI LINGKUNGAN KAMPUS UNIVERSITAS TRUNOJOYO MADURA
}

\author{
Mei Mita Bella, Luluk Widya Ratna \\ Universitas Trunojoyo Madura
}

\begin{abstract}
The behavior the lazy learning, campus environment The background of this study is that there is a phenomenon Trunojoyo Madura University students who have lazy learning behavior. In connection with this problem the researcher views that the lazy behavior of students learning Trunojoyo Madura University related to the environment. The formulation of the problem in these study are: (1) what are the factors that cause student learning lazziness? (2) how are the forms of student lazy learning behavior? As for the purpose in this study is (1) knowing the factors that cause lazy student learning, (2) find out the factors that cause lazy student learning. We only observe on the campus of the Trunojoyo Madura University whose subjects are students Trunojoyo Madura University. After we made the observations, the author uses data analysis with qualitative descriptive. After being analyzed, then the conclusion is obtained, that there is a lazy attitude to studying students in the campus of Trunojoyo Madura University, the cause of lazy student learning arises from within the student (internal) and from the outside (external). Because internally, among others, because of fatigue, tiredness and no motivation to learn. Because Externally, among others, because lecturers are less attractive in delivering lectures, the habits of friends in boarding houses are rarely studied. In the campus environment also found that there were some students who were lazy to learn. From various theories that exist that the environment has an influence on one's attitudes and behavior. This article is useful for writers to gain insight into the mindset, attitude and experience as an effort to improve the spirit of learning. For Trunojoyo Madura University as a contribution to scientific thought in the context of fostering students,
\end{abstract}

Keywords: both lecturers and educational institutions to pay attention to their students.

\section{PENDAHULUAN}

Kampus merupakan tempat menimba ilmu bagi para mahasiswa, memiliki peran penting dalam hal belajar. Lingkungan kampus yang ada, seperti perpustakaan, ruang belajar, laboratorium, masjid, kantor, dosen dan karyawan, dapat memberikan konstribusi terhadap perkembangan keilmuan mahasiswa. Mahasiswa memiliki bekal untuk mencari, menggali, dan mendalami bidang keilmuan dengan cara membaca, mengamati, memilih bahan-bahan bacaan untuk ditelaah, selanjutnya dituangkan dalam berbagai karya ilmiah. Belajar di perguruan tinggi sangat menyenangkan, mengasyikkan, dan memiliki keunikan 
tersendiri, terutama dalam memahami sesuatu, kita diberi kebebasan dan keleluasaan dalam berpikir, bereksperimen dan berkreativitas. Mahasiswa diberi keleluasaan karena dianggap sebagai orang dewasa yang tahu akan kebutuhannya, untuk bekal hari esok, dan berkewajiban untuk mematuhi segala peraturan yang ada. Ketika di sekolah, guru lebih banyak berperan besar dalam memberikan pelajaran yang menyebabkan siswa bersifat pasif, ketergantungan siswa pada guru sangatlah tinggi, sedangkan di perguruan tinggi para mahasiswa tidak sepenuhnya menggantungkan diri pada dosen. Materi yang diberikan oleh dosen, bukan untuk diterima secara mutlak tapi untuk di analisis, dikritik dan dicari bahan bandingannya, karena itu materi yang diberikan oleh dosen bukan segala-galannya tapi hanya sekedar perangsang untuk memotivasi mahasiswa agar mereka mampu mengkaji secara kritis materi perkuliahan yang diberikan dosen."Sebenarnya belajar di perguruan tinggi bukan suatu pekerjaan yang berat, karena tidak terlalu padat seperti belajar di SMA.

Di perguruan tinggi mahasiswa hanya mengikuti kuliah pada hari-hari dan jam-jam tertentu saja, kondisi tersebut sebenarnya menguntungkan, karena mahasiswa dapat memanfaatkan waktu yang tersedia dengan berbagai macam kegiatan, baik akademik maupun non akademik".Secara formal mahasiswa adalah "peserta didik yang terdaftar dan belajar pada suatu perguruan tinggi". "Mahasiswa harus belajar mengenali dan memahami diri sendiri. Mahasiswa berasal dari terjemahan student yang berarti a person who studies or investigates, yaitu seseorang yang belajar dan meneliti, dan to study dapat disimpulkan sebagai menggunakan akal pikiran secara aktif dan cermat serta penuh perhatian untuk dapat memahami suatu ilmu pengetahuan. Dengan kata lain mahasiswa atau student harus aktif belajar secara mandiri maupun dengan bimbingan dan arahan dosen".Mahasiswa ratarata memiliki usia antara 19-21 tahun, dalam usia tersebut mengalami perkembangan masa remaja akhir menuju dewasa awal. "Sebagai mahasiswa yang sedang memasuki tahap kematangan dan kemandirian dari masa remaja ke masa dewasa, pada kondisi seperti ini pola hidup yang tidak tepat akan membawa mahasiswa pada tingkat kejenuhan, kemalasan dan kebosanan belajar. Jika motivasi kurang, dosen tidak kolaboratif, tidak menarik dalam menyampaikan kuliah, jarang masuk, atau menyampaikan materi yang itu-itu saja, mahasiswa akan merasa jenuh dan malas belajar". Keberhasilan belajar di perguruan tinggi juga dipengaruhi oleh lingkungan pergaulan, jika bergaul dengan lingkungan yang kondusif, mahasiswa tidak mengalami hambatan dalam belajar. Tetapi jika berada dalam lingkungan pergaulan yang tidak kondusif, mahasiswa akan mengalami banyak hambatan 
belajar. Tidak sedikit mahasiswa yang mengalami droup-out karena pengaruh lingkungan pergaulan. Ada saja problematik yang dialami para mahasiswa, sehingga dapat menjadi hambatan dalam belajar, seperti kesulitan mengikuti perkuliahan, kejenuhan dan kemalasan, kurangnya motivasi, tidak mampu mengelola waktu, keuangan, pergaulan, tempat tinggal, masalah cinta dan sebagainya. Problematik tersebut merupakan suatu hal yang sering ada dalam kehidupan mahasiswa, dan untuk mengatasinya tidaklah mudah, mahasiswa harus belajar mengatasi hambatan-hambatan yang ada, agar proses belajar di perguruan tinggi dapat berjalan dengan lancar. "Ada satu lakon klasik yang belum usai dipentaskan di panggung sandiwara pendidikan kita sampai hari ini, dosen yang susah payah mengajar di depan, sementara mahasiswanya tidak memperhatikan, ada yang tertidur, sebagian ngerumpi, dan sisanya melamun sendiri. Ujung cerita ini biasanya mudah ditebak, sang dosen meledak, dan suasana kelas jadi tak enak. Proses belajarmengajar (PBM) rusak". "Banyak masalah yang terjadi dan akan terus dihadapi seorang mahasiswa selama proses perkuliahan, masalah itu muncul dan terjadi karena dari dalam diri mahasiswa itu sendiri dan juga lingkungan sekitarnya”.

Belajar di perguruan tinggi memakan waktu yang tidak sebentar. Hal ini seringkali mendatangkan rasa jenuh dan malas belajar. Belum lagi tuntutan kemandirian yang lain, yang relatif cepat pada masa mengikuti kuliah, yang akan membawa pengaruh terhadap kehidupan psikis. Kejenuhan belajar dapat timbul baik dalam diri mahasiswa itu sendiri maupun dari luar diri mahasiswa. Dari dalam diri sendiri misalnya rasa bosan dan kurangnya motivasi diri. Mahasiswa belum dapat menanamkan dalam dirinya bahwa belajar itu suatu yang menyenangkan. Belajar masih dianggap suatu beban dan kewajiban, sehingga belajar menjadi sesuatu yang membosankan. Untuk memahami mengapa mahasiswa malas belajar, dan untuk membantu mencari cara pencegahan serta jalan keluarnya, perlu mengkaji sebuah teori yang dikemukakan oleh Urie Bronfrenbrenner yang dipaparkan oleh Sarlito Wirawan Sarwono (2003). Teori Urie Bronfrenbrenner yang berparadigma lingkungan (ekologi) ini menyatakan bahwa perilaku seseorang (termasuk perilaku malas belajar pada mahasiswa) tidak berdiri sendiri, melainkan merupakan dampak dari interaksi orang yang bersangkutan dengan lingkungan di luarnya. "Adapun lingkungan di luar diri oleh Urie Bronfrenbrenner di bagi dalam beberapa lingkaran yang berlapis-lapis, yakni: 
1. Lingkaran pertama adalah yang paling dekat dengan pribadi, yaitu lingkaran sistem mikro yang terdiri dari keluarga, kampus, dosen, tetangga, rumah, dan sebagainya yang sehari-hari ditemui.

2. Lingkaran kedua adalah interaksi antar faktor-faktor dalam sistem mikro (hubungan orangtua dan guru, orangtua dan teman, antar teman, guru dan teman dan sebagainya) yang dinamakannya sistem meso.

3. Lingkaran ketiga yang disebut sistem exo, yaitu lingkaran lebih luar lagi, yang tidak langsung menyentuh pribadi, akan tetapi masih besar pengaruhnya, seperti keluarga besar, koran, televisi.

4. Lingkaran yang paling luar adalah sistem makro, yang terdiri dari ideologi negara, pemerintah, tradisi, agama, hukum, adat, budaya".

Untuk dapat melakukan suatu pekerjaan dengan baik, seseorang harus mempunyai motivasi, begitu juga dengan belajar di perguruan tinggi. Motivasi adalah dorongan dari dalam diri untuk melakukan sesuatu, motivasi belajar yang kuat adalah kunci utama untuk dapat berhasil di perguruan tinggi. "Keberhasilan seseorang dalam belajar sangat dipengaruhi oleh kesungguhan, minat dan motivasi seseorang. Motivasi yang kuat akan menghasilkan sikap sebagai mahasiswa yang:

a. Selalu memelihara kesungguhan, ketekunan dan semangat dalam belajar.

b. Pantang menyerah.

c. Kuat terhadap berbagai godaan, baik yang datang dari dalam maupun luar.

d. Pandai bergaul dan tetap menjaga hubungan baik dengan sesama.

e. Menjalankan perintah agama serta meninggalkan hal-hal yang dilarang”.

Selain menarik, perilaku malas belajar ini juga penting untuk dikaji. Penelitian ini mempunyai fokus pada perilaku malas belajar mahasiswa dan lingkungan kampus. Dan penulis menuangkan dalam judul Perilaku Malas Belajar Mahasiswa di Lingkungan Kampus.Untuk memudahkan pemahaman dan menghindari kesalahpahaman dari konsep judul ini, penulis akan mengemukakan beberapa istilah, sehingga terhindar dari perluasan makna atau uraian.

\section{Secara konseptual}

a. Perilaku adalah "tanggapan atau reaksi individu terhadap rangsangan atau lingkungan". "Perilaku manusia adalah sebagai suatu fungsi dari interaksi antara individu dengan lingkungannya". 
b. Malas adalah "tidak mau bekerja atau mengerjakan sesuatu. Malas juga berarti segan, tidak suka, tidak bernafsu".

c. Belajar adalah "suatu proses usaha yang dilakukan individu untuk memperoleh suatu perubahan tingkah laku yang baru secara keseluruhan sebagai hasil pengalaman individu itu sendiri dalam interaksi dengan lingkungan".

d. Malas belajar "berarti tidak mau, enggan, tak suka, dan tak bernafsu untuk belajar".

e. Mahasiswa adalah "orang yang belajar di perguruan tinggi".

f. Lingkungan adalah "daerah (kawasan) yang termasuk didalamnya".

g. Kampus adalah "daerah lingkungan bangunan utama perguruan tinggi (universitas, akademik) tempat semua kegiatan belajar dan administrasi berlangsung".

\section{Secara operasional}

Secara operasional yang dimaksud dengan perilaku malas belajar mahasiswa adalah kegiatan mahasiswa yang menunjukkan perilaku enggan atau tidak mau belajar. Lingkungan kampus adalah lingkungan yang ada didalam kampus seperti ruang kuliah, laboratorium, kantor, tempat parkir, perpustakaan, masjid, mahasiswa, dosen, dan karyawan. Jadi yang dimaksud dengan perilaku malas belajar mahasiswa di lingkungan kampus adalah kegiatan mahasiswa di lingkungan yang ada dalam kampus yang menunjukkan perilaku tidak mau belajar.

\section{TINJAUAN PUSTAKA}

\section{Definisi mahasiswa}

"Mahasiswa adalah kelompok manusia penganalisis yang bertanggung jawab untuk mengembangkan kemampuan penalaran individual". Mahasiswa adalah "orang yang belajar di perguruan tinggi”. Pengertian tersebut terkait dengan orang yang tengah belajar, berusaha untuk mencari ilmu pengetahuan, pengalaman, keterampilan dan pembentukan kepribadian untuk bekal hidupnya di masa depan agar berbahagia di dunia dan akhirat. Seorang mahasiswa sudah memiliki bekal untuk mencari, menggali dan mendalami bidang keilmuan yang diminatinya dengan cara membaca, mengamati, memilih bahan-bahan bacaan untuk ditelaah selanjutnya dituangkan dalam berbagai karya ilmiah. Mahasiswa juga kental dengan nuansa kedinamisan dan sikap keilmuannya yang dalam melihat 
sesuatu berdasarkan kenyataan objektif, sistematis, dan rasional. "Sebagai mahasiswa harus belajar mengenali dan memahami diri sendiri, mahasiswa berasal dari terjemahan student yang berarti a person who studies or investigates, yaitu seorang yang belajar dan meneliti, to study dapat disimpulkan sebagai menggunakan akal pikiran secara aktif dan cermat serta penuh perhatian untuk dapat memahami suatu ilmu pengetahuan. Dengan kata lain mahasiswa atau student harus aktif belajar secara mandiri maupun dengan bimbingan dan arahan dosen".

"Mahasiswa merupakan anggota masyarakat yang memiliki ciri-ciri tertentu, antara lain:

1. Mempunyai kemampuan dan kesempatan untuk belajar di perguruan tinggi, sehingga dapat digolongkan sebagai kaum intelegensia

2. Karena kesempatan diatas, diharapkan nantinya dapat bertindak sebagai pemimpin yang mampu dan terampil, baik sebagai pemimpin masyarakat ataupun dalam dunia kerja

3. Diharapkan dapat menjadi daya penggerak yang dinamis bagi proses modernisasi

4. Diharapkan dapat memasuki dunia kerja sebagai tenaga yang berkualitas dan profesional".

\section{Tipologi mahasiswa}

Secara umum, terdapat dua kategori mahasiswa yang didasarkan pada karakter mahasiswa. "Pertama, mahasiswa akademis adalah mahasiswa yang menonjol dalam hal perkuliahan". "Mahasiswa akademisi adalah mahasiswa yang menjadikan kuliah sebagai kewajiban, aktif kuliah dengan presensi yang lengkap, tugas kuliah diselesaikan dengan baik, kuliah tepat waktu dengan indeks prestasi akademik yang sempurna atau cum laude. Kedua, mahasiswa aktivis adalah mahasiswa yang lebih memilih aktif di luar bangku kuliah dengan berproses di organisasi kemahasiswaan baik intra maupun ekstra kampus, indeks prestasi akademik yang pas-pasan, masa kuliah yang tidak pasti bahkan nyaris drop out (DO)". Dari dua tipologi yang berseberangan tersebut, tampak jelas fenomena kehidupan mahasiswa. Apabila termasuk dalam kategori pertama, maka jalan yang mahasiswa lalui selama masa kuliah tidak jauh dari lingkaran kos dan kampus. Sedangkan jika termasuk dalam kategori kedua banyak jalan yang dilalui di luar kampus selama masa kuliah, sehingga hampir pasti tidak pernah menginjakkan kakinya di lantai kampus. 
Menurut pendapat kami, idealnya mahasiswa memiliki kehidupan yang seimbang antara aktivitas akademik dan nonakademik. Dengan begitu, ketika lulus, yang diperoleh bukan hanya gelar melainkan juga peningkatan kualitas diri sehingga memiliki daya saing ketika terjun ke dunia nyata.

\section{Pengertian Lingkungan}

"Lingkungan adalah daerah atau kawasan yang termasuk didalamnya". Pengertian lingkungan adalah "tempat dimana suatu makhluk hidup itu tumbuh dimana meliputi unsur-unsur penting seperti tanah, air dan udara, lingkungan sendiri memiliki arti penting dalam kehidupan setiap makhluk hidup". Lingkungan merupakan "segala hal yang mempengaruhi individu, sehingga individu itu terlibat atau terpengaruh karenannya. Individu akan menerima pengaruh dari lingkungan, memberi respon kepada lingkungan, mencontoh atau belajar tentang berbagai hal dari lingkungan".

Menurut Sertain (ahli psikologi Amerika), yang dipaparkan oleh M. Dalyono (2007) bahwa "lingkungan adalah meliputi semua kondisi-kondisi dalam dunia ini yang dengan cara-cara tertentu mempengaruhi tingkah laku kita, pertumbuhan dan perkembangan kecuali gen-gen”. Menurut F. Partty seperti yang dikutip oleh Baharuddin (2007) "lingkungan merupakan sesuatu yang mengelilingi individu di dalam hidupnya, baik dalam bentuk lingkungan fisik seperti orang tua, rumah, kawan bermain dan masyarakat sekitar, maupun dalam bentuk lingkungan psikologis seperti perasaan-perasaan yang dialami, cita-cita, persoalan-persoalan yang dihadapi dan sebagainya". Dari beberapa pengertian diatas dapat diambil kesimpulan bahwa lingkungan adalah segala sesuatu yang ada disekitar kita, seperti: alam, iklim, cuaca dan semua makhluk hidup yang ada di dunia ini yang dapat mempengaruhi tingkah laku, pertumbuhan dan perkembangan manusia. Yang mana individu nantinya akan menerima pengaruh dari lingkungan, memberi respon kepada lingkungan, mencontoh atau belajar tentang berbagai hal dari lingkungan.

\section{Pengertian Belajar}

Dalam proses pendidikan, belajar merupakan kegiatan inti. "Secara psikologis belajar dapat diartikan sebagai proses memperoleh perubahan tingkah laku (baik dalam kognitif, afektif, maupun psikomotor) untuk memperoleh respons yang diperlukan dalam interaksi dengan lingkungan secara efisien". "Dalam kegiatan belajar dapat timbul 
berbagai masalah baik bagi mahasiswa itu sendiri maupun bagi pengajar atau dosen. Bagi mahasiswa sendiri, masalah-masalah belajar yang mungkin timbul misalnya pengaturan waktu belajar, memilih cara belajar, menggunakan buku-buku kuliah, mengerjakan tugas kuliah, dan sebagainya. Menurut James O. Whittaker (2004), belajar dapat didefinisikan sebagai proses dimana tingkah laku ditimbulkan atau diubah melalui latihan atau pengalaman". Para ahli memberikan definisi yang beragam pada kata "belajar".

Belajar(learning)menurut psikologis , perubahan tingkah laku seseorang terhadap suatu situasi tertentu yang disebabkan oleh pengalamannya secara berulang-ulang dalam situasi itu, di mana perubahan dalam tingkah laku itu tidak dapat dijelaskan atau dasar kecenderungan respon pembawaan, kematangan, atau keadaan-keadaan sesaat seseorang (misalnya kelelahan, pengaruh obat). Menurut pengertian secara psikologi, belajar merupakan suatu proses perubahan yaitu perubahan di dalam tingkah laku sebagai hasil interaksi dengan lingkungannya dalam memenuhi kebutuhan hidupnya. Perubahanperubahan tersebut akan dinyatakan dalam seluruh aspek tingkah laku. Pengertian belajar dapat didefinisikan sebagai berikut "belajar adalah suatu proses usaha yang dilakukan individu untuk memperoleh suatu perubahan tingkah laku yang baru secara keseluruhan sebagai hasil pengalaman individu itu sendiri dalam interaksi dengan lingkungan”. Jadi belajar merupakan proses dari perkembangan hidup manusia.

Dengan belajar, manusia melakukan perubahan-perubahan kualitatif individu sehingga tingkah lakunya berkembang. Semua aktivitas dan prestasi hidup lain adalah hasil dari belajar. Manusia pun hidup menurut hidup dan bekerja menurut apa yang telah kita pelajari.

\section{Pengertian Malas Belajar}

Malas adalah "tidak mau bekerja atau mengerjakan sesuatu. Malas juga berarti segan, tidak suka, tidak bernafsu". Malas belajar "berarti tidak mau, enggan, tak suka, dan tak bernafsu untuk belajar". "Malas adalah kebiasaan yang dipelajari dan dibentuk oleh kondisi lingkungan dan orang-orang sekitarnya". "Sifat malas adalah akibat ketidakmampuan mengelola waktu dan tiadanya disiplin diri, bukan sifat bawaan. Oleh sebab itu, agar sifat malas ini tidak terbentuk, perlu dibiasakan untuk menghargai waktu dan disiplin. Jepang dan Cina bisa menjadi negara yang maju pesat karena manusianya dikenal memiliki sifat gigih, tekun, dan pekerja keras". 
Psikologi LPT UNIKA Soegijapranata Semarang, Drs. Haryo Goeritno, Msi, (2009) seperti yang dikutip oleh Imam Musbikin mengatakan bahwa "pada dasarnya tidak ada karakter khusus yang dapat dijadikan patokan sifat malas atau tidak karena malas bersifat sementara. Umumnya, sifat malas senantiasa dibandingkan antara kegiatan yang biasanya dilakukan dengan kegiatan yang tengah dilakukan saat itu. Karenanya, ukuran malas tergantung pada aktivitas orang-orang yang ada disekitarnya". Setiap orang bisa berperilaku malas terhadap suatu pekerjaan atau kegiatan karena tidak memiliki motivasi untuk melakukan pekerjaan atau kegiatan itu. "Dalam psikologi, seseorang berperilaku tertentu karena adanya energi yang mendorongnya untuk berperilaku. Energi inilah yang disebut motivasi, yakni yang mendorong seseorang bertingkah laku mencapai suatu tujuan". "Motivasi dipengaruhi oleh suatu sikap yang terdapat dalam diri orang itu. Sikap itu timbul lantaran adanya persepsi atau pemberian makna terhadap suatu objek atau peristiwa. Persepsi atau pemberian makna tersebut ditentukan oleh suatu sistem nilai, yani suatu patokan untuk berperilaku yang berlaku pada suatu lingkungan tertentu. Sistem nilai yang tertanam dalam diri seseorang ini dipengaruhi oleh budaya, masyarakat, dan orang tua".

Dalam hal ini, malas belajar ditunjukkan terjadi lantaran tidak memiliki motivasi untuk melakukan tugas. Perilaku tersebut muncul karena dibenaknya tertanam persepsi yang salah terhadap tugas yang diberikan. Misalnya belajar itu melelahkan atau tak ada gunanya. Persepsi semacam itu bisa terjadi kalau lingkungan sekitar yang ada kurang tertanam budaya belajar.

1. Perilaku malas belajar mahasiswa

Belajar di perguruan tinggi memakan waktu yang tidak sebentar, hal ini sering mendatangkan rasa malas belajar. Belum lagi mahasiswa dihadapkan pada banyak tugas dan ujian, yang akan membawa pengaruh terhadap kehidupan psikis. "Memasuki dunia perguruan tinggi berarti melibatkan diri dalam situasi hidup dan situasi akademis yang secara fundamental berbeda dengan apa yang pernah dialami dalam lingkungan sekolah lanjutan atas.

Perguruan tinggi bukan sekedar lanjutan dari sekolah lanjutan atas, tetapi merupakan suatu yang hakiki dari taraf pendidikan tinggi itu sesuai tuntutan pendidikan tinggi itu". Sebagai konsekuensinya, bahwa manusia wajib mengadakan adaptasi dengan dunia baru ini yang penuh dengan liku-liku dan 
seluk beluknya serta resiko, terutama adaptasi pola berpikir, belajar, berkreasi, bertindak dalam kehidupan kampus ini. Ini memerlukan kesadaran dari mahasiswa bahwa ia berada di antara berbagai ragam problema secara sendirian, yang sangat jauh berbeda dengan situasi sekolah lanjutan atas yang relatif mudah memperoleh bimbingan dan penyuluhan. "Sejalan dengan perubahan dalam masyarakatnya, mahasiswa juga mengalami pancaroba dalam dirinya menuju taraf kedewasaannya. Untuk menjawab tantangan ini dibutuhkan suatu sikap mental yang tangguh dan serasi dengan tuntutan hidup di dunia ini. Jawaban ini pun dapat diberikan karena mahasiswa secara fisik telah mencapai taraf kedewasaan atau kematangan rasional dan emosional untuk mendidik dan membentuk dirinya sendiri menjadi seorang ilmuan/intelektual.

Dari mahasiswa diharapkan adanya jiwa yang bebas terbuka, pikiran yang aktif, kritis, dan kreatif". "Sebagai mahasiswa yang sedang memasuki tahapan kematangan dan kemandirian dari masa remaja ke masa dewasa. Pada kondisi ini, pola hidup yang tidak tepat akan membawa mahasiswa pada tingkat kejenuhan, kemalasan dan kebosanan belajar". Malas belajar dapat timbul baik dalam diri mahasiswa itu sendiri maupun dari luar diri mahasiswa. Dari dalam diri sendiri misalnya rasa bosan dan kurangnya motivasi diri. Mahasiswa belum dapat menanamkan dalam dirinya bahwa belajar itu suatu yang menyenangkan. Belajar masih dianggap suatu beban dan kewajiban, sehingga belajar menjadi sesuatu yang membosankan. Dari luar misalnya dosen kurang kreatif dalam menyampaikan materi kuliah, sehingga terkesan monoton dan tidak menarik.

2. Faktor-Faktor Penyebab Malas Belajar Mahasiswa

Belajar sebagai proses atau aktivitas disyaratkan oleh banyak sekali hal-hal atau faktor-faktor. Faktor-faktor yang mempengaruhi belajar itu ada banyak sekali macamnya. Untuk memudahkan memahaminya dapat dilakukan klasifikasi demikian:

a. Faktor - faktor yang mempengaruhi belajar

1) Faktor-faktor non sosial dalam belajar 
"Kelompok faktor-faktor ini boleh dikatakan juga tak terbilang jumlahnya, seperti misalnya: keadaan udara, suhu ucara, cuaca, waktu (pagi, siang, ataupun malam), tempat (letaknya, pergedungannya), alatalat yang dipakai untuk belajar". Faktor tersebut harus diatur sedemikian rupa agar dapat membantu proses belajar secara maksimal.

2) Faktor-faktor sosial dalam belajar

"Yang dimaksudkan dengan faktor-faktor sosial di sini adalah faktor manusia (sesama manusia), baik manusia itu ada (hadir) maupun kehadirannya itu dapat disimpulkan, jadi tidak langsung hadir. Kehadiran orang lain pada waktu seseorang sedang belajar, banyak mengganggu belajar". Misalkan kalau satu kelas sedang mengikuti kuliah, lalu terdengar banyak mahasiswa lain bercakap-cakap di samping kelas. Faktor-faktor sosial tersebut pada umumnya bersifat mengganggu proses belajar.

3) Faktor-faktor fisiologis dalam belajar

"Keadaan jasmani pada umumnya ini dapat dikatakan melatar belakangi aktivitas belajar, keadaan jasmani yang kurang segar, keadaan jasmani yang lelah lain pengaruhnya daripada yang tidak lelah". Nutrisi harus cukup karena kekurangan kadar makanan akan mengakibatkan malas belajar, kelesuan, lekas mengantuk, lekas lelah.

4) Faktor-faktor psikologi dalam belajar

Arden N. Frandsen (2004), seperti yang dikutip oleh Sumadi Suryabrata mengatakan bahwa "hal yang mendorong seseorang untuk belajar itu adalah sebagai berikut:

- Adanya sifat ingin tahu dan ingin menyelidiki dunia yang lebih luas

- Adanya sifat yang kreatif yang ada pada manusia dan keinginan untuk selalu maju

- Adanya keinginan untuk mendapatkan simpati dari orang tua, guru, dan teman-teman

- Adanya keinginan untuk memperbaiki kegagalan yang lalu dengan usaha yang baru, baik dengan koperasi maupun dengan kompetisi 
- Adanya keinginan untuk mendapatkan rasa aman bila menguasai pelajaran

- Adanya ganjaran atau hukum sebagai akhir dari pada belajar”.

Faktor-faktor yang mempengaruhi belajar yang telah dikemukakan di atas tidaklah lepas satu sama lain, melainkan sebagai suatu keseluruhan (suatu kompleks) mendorong belajar peserta didik.

b. Faktor penyebab malas belajar

Faktor-faktor penyebab malas belajar mahasiswa dipengaruhi oleh berbagai faktor, baik internal (yang bersumber dari dalam diri sendiri) maupun eksternal (yang bersumber dari luar atau lingkungan).

1) Faktor internal

"Ada beberapa faktor yang harus dipenuhi agar berhasil dalam belajar. Syarat-syarat itu meliputi fisik dan psikis. Yang termasuk faktor fisik, diantaranya: nutrisi (gizi makanan), kesehatan dan keberfungsian fisik (terutama pancaindra). Kekurangan nutrisi dapat mengakibatkan kelesuan, lekas mengantuk, lekas lelah, dan kurang bisa konsentrasi. Penyakit juga bisa mempengaruhi keberhasilan belajar, oleh karena itu, pemeliharaan yang intensif sangat penting bagi individu. Sementara yang termasuk faktor psikis di antaranya adalah kecerdasan, motivasi, minat, sikap, dan kebiasaan belajar, dan suasana emosi". Apabila kedua faktor tersebut tidak terpenuhi atau mengalami gangguan, maka kemungkinan besar mahasiswa akan mengalami malas dalam belajar.

2) Faktor eksternal

"Faktor ini meliputi aspek-aspek sosial dan nonsosial. Yang dimaksud dengan faktor sosial adalah faktor manusia. Sedangkan yang termasuk faktor non sosial adalah keadaan suhu udara (panas, dingin) waktu (pagi, siang, malam), suasana lingkungan (sepi, bising, ramai), keadaan tempat (kualitas gedung, luas ruangan, kebersihan, dan ventilasi), kelengkapan alat-alat atau fasilitas belajar (alat peraga, bukubuku sumber, dan media komunikasi belajar lainnya)". Jadi jelas dalam 
kegiatan belajar ini banyak masalah-masalah yang timbul terutama yang dirasakan oleh mahasiswa sendiri.

\section{Bentuk-Bentuk Perilaku Malas Belajar Mahasiswa}

Untuk memperoleh informasi tentang bentuk-bentuk malas belajar mahasiswa, peneliti menggunakan metode deskriptif untuk mendapatkan keterangan jawaban dari subjek. Dari hasil yang diperoleh kesimpulan bahwa bentuk-bentuk perilaku malas belajar mahasiswa di lingkungan kampus meliputi:

1. Tidak masuk kuliah (sering absen)

2. Sering datang terlambat

3. Tidak mengerjakan tugas kuliah

4. Tidak memperhatikan dosen yang sedang mengajar (asik berbicara dengan teman ketika dosen menyampaikan pelajaran)

5. Tidur atau mengantuk didalam kelas saat proses pembelajaran

6. Bermain hp di saat jam kuliah (sms dan menerima telpon saat jam pelajaran

7. Jika ada tugas kelompok tidak mau mengerjakan, bergantung pada teman yang lain

8. Belum belajar atau melakukan persiapan ketika akan presentasi makalah, akibatnya jalannya diskusi kurang menarik, karena belum menguasai dan memahami makalah.

Perilaku malas belajar mahasiswa juga terlihat di lingkungan kampus. Bentukbentuk perilaku malas belajar mahasiswa juga beraneka ragam antara mahasiswa satu dengan mahasiswa yang lain.

\section{METODE PENELITIAN}

\section{Pendekatan dan Jenis Penelitian}

Suatu penelitian ilmiah tidak lepas dari adanya tujuan yang ingin dicapai. Tujuan tersebut erat kaitannya dengan pemikiran metode yang akan digunakan. Penggunaan metode yang tepat akan mencapai tujuan yang telah direncanakan secara efektif dan efisien. Berdasarkan latar belakang yang telah dipaparkan di awal, maka peneliti berusaha mengungkap serta menjawab dari fokus penelitian. Untuk itu peneliti dalam melakukan penelitiannya menggunakan penelitian kualitatif. "Penelitian kualitatif adalah penelitian 
yang bermaksud untuk memahami fenomena tentang apa yang dialami oleh subyek penelitian misalnya perilaku, persepsi, motivasi, tindakan dan lain-lain, dan dengan cara deskripsi dalam bentuk kata-kata dan bahasa, pada suatu konteks khusus yang alamiah dan dengan memanfaatkan berbagai metode alamiah".

Dalam penelitian ini menggunakan metode penelitian diskriptif. "Penelitian deskriptif merupakan metode penelitian yang berusaha menggambarkan dan menginterpretasi obyek sesuai dengan apa adanya". "Penelitian kualitatif merupakan suatu pendekatan dalam melakukan penelitian yang berorientasi pada fenomena atau gejala yang bersifat alami”. Adapun jenis penelitian yang dilakukan dalam pnelitian ini adalah "etnometodologi yaitu cara (metodologi yang digunakan) orang untuk memahami situasi tempat mereka berada. Etnometodolog berusaha memahami bagaimana orang-orang melihat, menerangkan, dan menguraikan keteraturan dunia tempat mereka". Dilihat dari mana data diperoleh, maka penelitian ini termasuk jenis penelitian lapangan (field research) yaitu jenis penelitian yang berorientasi pada pengumpulan data yang empiris dari lapangan. Penelitian ini merupakan studi kasus dari fenomena mahasiswa yang memiliki perilaku malas belajar.

Penelitian kualitatif merupakan upaya dalam menjawab permasalahan dengan mendiskripsikan data sebagaimana adanya, dari sudut pandang subyek sendiri yang tidak terlepas dari setting kajian. Tujuan penelitian ini untuk menjawab pertanyaan inti dari fokus penelitian yaitu penulis ingin mengungkapkan lebih detail tentang faktor-faktor penyebab malas belajar mahasiswa, dan bentuk-bentuk perilaku malas belajar mahasiswa di lingkungan kampus.

\section{Subyek Penelitian}

Subyek dalam penelitian ini adalah empat orang mahasiswa. Pada dasarnya mahasiswa tersebut memiliki perilaku yang malas belajar. Adapun karakteristik subjek tersebut adalah sebagai berikut:

1. Mahasiswa semester iii

2. Mahasiswa tersebut berjenis kelamin laki-laki dan perempuan

3. Mahasiswa tersebut memiliki perilaku malas belajar

4. Mahasiswa berusia antara 19-22 tahun 
Sedangkan menurut Burhan Bungin (2001), "karakteristik subjek adalah sebagai berikut:

1. Orang yang bersangkutan memiliki pengalaman pribadi sesuai dengan permasalahan yang diteliti

2. Orang yang bersangkutan telah dewasa

3. Orang yang bersangkutan sehat jasmani dan rohani

4. Orang yang bersangkutan bersifat netral

5. Orang yang bersangkutan memiliki pengetahuan yang luas mengenai permasalahan yang diteliti”.

\section{Lokasi Penelitian}

Peneliti memilih Universitas Trunojoyo Madura sebagai tempat penelitian, karena di tempat tersebut terdapat beberapa mahasiswa yang memiliki perilaku malas belajar. Selain itu peneliti memiliki beberapa alasan diantaranya:

1. Kehidupan mahasiswa syarat dengan idealis yang dibangun mulai dari awal masuk kampus.

2. Latar belakang mahasiswa yang beraneka ragam.

3. Adanya perilaku malas belajar mahasiswa yang perlu untuk dikaji.

\section{Sumber Data}

"Jenis data dalam penelitian kualitatif terdiri dari dua jenis yaitu data yang bersumber dari manusia dan bersumber dari non manusia". Sumber data manusia berupa orang yang dijadikan sumber informasi dan dianggap mengetahui secara jelas informasi dan permasalahan yang akan diteliti. Sedangkan sumber data non manusia berupa dokumen yang berkaitan dengan fokus penelitian seperti pedoman observasi, pedoman wawancara. Sumber data penelitian ini adalah subyek dari mana data dapat diperoleh, diklasifikasikan menjadi tiga bagian, yaitu sumber data yang berupa orang (person) sumber data berupa tempat (place) dan sumber data berupa simbol (paper) yang cocok untuk penggunaan metode dokumentasi.

Adapun yang menjadi sumber data dalam penelitian ini adalah mahasiswa dan kegiatan yang ada di kampus Universitas Trunojoyo Madura. Kegiatan mahasiswa tersebut dapat peneliti kumpulkan berupa dokumen dan arsip, baik dalam dokumen sekolah 
ataupun dokumen peneliti dari lapangan. Untuk memperoleh informasi tentang perilaku malas belajar mahasiswa Universitas Trunojoyo Madura yang relevan, maka penelitian ini selain memilih informasi yang dianggap paling mengetahui masalah yang dikaji, juga cara memilihnya dikembangkan sesuai kebutuhan dan kemantapan dalam pengumpulan data.

\section{Teknik Pengumpulan Data}

Pada penelitian kualitatif pada dasarnya teknik pengumpulan data yang lazim digunakan adalah observasi, wawancara. "Kegiatan pengumpulan data yang dilakukan dengan observasi dan wawancara mendalam untuk menjelajahi dan melacak memadai mungkin realitas fenomena yang tengah di studi”.

\section{Metode observasi}

Observasi adalah penelitian yang mengambil datanya bertumpu pada pengamatan langsung terhadap obyek penelitian. Peneliti perlu menjamin keakraban dengan responden untuk menggali data yang lebih akurat. Peneliti juga akan mengamati aktivitas mahasiswa terutama yang berhubungan dengan aktifitas belajar mereka.

2. Metode wawancara

"Wawancara adalah percakapan dengan maksud tertentu", untuk mengetahui apa yang terkandung dalam pikiran, perasaan atau hati orang lain, maka untuk mengetahui maksud dari ungkapan subjek dalam wawancara mendalam diperlukan ketelitian. Asumsi dasar wawancara mendalam adalah "bahwa makna yang diberikan individu terhadap pengalamannya berpengaruh terhadap cara mereka membawa pengalaman tersebut". Wawancara atau interview "merupakan metode penelitian dengan menggunakan pertanyaanpertanyaan, pertanyaan-pertanyaan diberikan secara lisan”. Pada interviu hal-hal yang kurang jelas dapat diperjelas, sehingga orang dapat mengerti apa yang dimaksudkan. Dalam interview adanya hubungan langsung (face to face) karena itu diharapkan dapat menimbulkan suasana hubungan yang baik, dan ini akan memberikan bantuan dalam mendapatkan bahan-bahan.

Metode wawancara dapat memberikan sumbangan yang besar dalam metode penelitian. Suatu hal yang penting pada interview ialah membuat pertanyaan-pertanyaan sedemikian rupa hingga yang diinterviw tidak merasa 
diinterviu dengan hal-hal yang telah disiapkan terlebih dahulu. Setelah peneliti memperoleh keterangan yang jelas, dapat menggunakan wawancara berstruktur. Untuk mendapatkan data yang lebih subjektif, peneliti tidak menggunakan catatan lapangan dengan maksud bahwa keberadaan peneliti dalam melakukan penggalian data tidak diketahui oleh subjek. Dengan tidak mencatat pada waktu di lapangan, subjek tidak mengetahui bahwa dirinya sedang diteliti. Proses dari wawancara dicatat dalam bentuk transkip yang berisi apa saja yang terjadi saat wawancara berlangsung.

\section{HASIL DAN PEMBAHASAN}

\section{Faktor-faktor penyebab malas belajar}

Wawancara dilakukan untuk memperoleh data sebanyak-banyaknya dan nantinya diseleksi dengan baik. Wawancara dilakukan dengan berbagai keadaan agar lebih leluasa untuk mengungkap apa yang ingin peneliti peroleh dari subjek. Mengenai penyebab malas belajar, berikut hasil wawancara peneliti dengan masing-masing subjek.

Mm : "Saya itu paling malas untuk belajar dan rasa malas ini kira-kira sejak saya semester II. Penyebabnya ya macam-macam. Kalau dirumah saya mempunyai banyak kegiatan, kalau sudah capek, biasanya malas untuk kuliah, kesibukan tersebut juga pengaruh terhadap kuliah. Tidak jarang di kampus saya kecapean, lelah, tidak konsen, akibatnya saya malas sekali belajar, seperti tidak punya nafsu belajar gitu, ya maklum sudah capek banget. Kalau di kampus kadang ada dosen yang kurang menarik dalam menyampaikan kuliah, hal tersebut membuat saya tambah malas belajar lagi".

Fl : "Rasa malas itu kadang-kadang muncul, pokoknya ngak semangat belajar. Sejak semester I pun rasa malas juga sudah mulai ada. Penyebab awalnya, sebenarnya dulu saya tidak tertarik untuk menjadi guru, saya kuliah tetapi jurusan yang saya ambil tidak sesuai dengan bakat dan minat saya. Saya itu kadang berpikir, apakah nanti setelah lulus saya akan mendapatkan pekerjaan yang baik dan mapan sesuai dengan jurusan yang saya ambil, untuk menjadi seorang guru!. Nah kalau dilihat kondisi sekarang ini, tenaga guru banyak diminati, 
banyak kabar juga bahwa guru sukuan pun sekarang sulit. Huh mendengar kabar-kabar seperti itu membuat saya jenuh, malas, bosan, buat apa saya konsentrasi penuh untuk belajar, kalau untuk kedepannya kurang jelas begini”.

Me : "Saya itu paling malas untuk belajar, rasa malas ini sejak saya semester II. Dikosan kan banyak teman gitu mbak, biasanya kami banyak menghabiskan waktu untuk sekedar ngobrol ini itu, liat tv, mendengarkan musik, ngrumpi, dan kami jarang banget belajar, paling-paling belajar pas mau ada ujian gitu. Kayak terbawa lingkungan gitu mbak, di tempat kos ada budaya santai, jadi saya juga santai-santai saja. Kadang saya juga tidak masuk kuliah kalau sedang malas".

St : "Sering saya merasa malas belajar. malas itu kadang-kadang muncul, pokoknya ngak semangat belajar, rasa malas ini sejak saya semester awal. Kalau dulu pas zaman sekolah saya rajin belajar, bahkan pernah dapat juara dikelas soalnya orang tua juga rajin menasehati saya untuk belajar, tapi setelah kuliah kok tambah malas, ngak pernah belajar. Kalau di tempat kos kita bebas ngapain aja, tidak ada yang nyuruh harus belajar, harus ini itu. Belum lagi masalah pacar, nah itu juga mengganggu belajar saya mbak, kan sering di sms, telpon, sedikit banyak ya mengganggu, tapi aku seneng karena ada yang perhatian, gitu deh mbak".

Dari hasil wawancara dengan subjek 1, yang terkait dengan sebab-sebab malas belajar adalah jawaban subjek pertama yakni: capek karena memiliki banyak kegiatan dirumah dan hal ini mengakibatnya malas belajar, dikampus merasa lelah, tidak konsentrasi, dan jika ada dosen yang kurang menarik dalam menyampaikan kuliah membuat subjek tambah malas belajar. Hasil wawancara dengan subjek 2, subjek tidak tertarik untuk menjadi guru padahal jurusan yang diambil adalah Tarbiyah (jurusan yang diambil kurang sesuai dengan bakat dan minat), hal ini menyebabkan subjek kurang memiliki semangat belajar. Wawancara dengan subjek 3, yang terkait dengan sebab-sebab malas belajar adalah subjek adalah anak kos yang banyak menghabiskan waktu untuk melihat tv, ngobrol dengan teman-temannya, jarang belajar, kehidupan di tempat kos yang 
santai, dan kadang juga tidak masuk kuliah jika sedang malas. Dari hasil wawancara dengan subjek 4, yang terkait dengan sebab-sebab malas belajar adalah semenjak kuliah subjek merasakan malas belajar, ditempat kos membuat subjek leluasa, dan pacaran ternyata juga membuat subjek malas belajar. Dari data diatas dapat dipamahi bahwa mahasiswa memiliki latar belakang yang beraneka ragam, memiliki kebiasaan, cara pikir, dan tingkah laku yang berbeda-beda. Dari wawancara peneliti dengan subjek bisa diambil kesimpulan bahwa penyebab malas belajar mahasiswa muncul dari dalam diri mahasiswa itu sendiri (sebab internal) dan dari luar (sebab eksternal). Sebab internal antara lain karena lelah, kecapean, tidak adanya motivasi belajar. Sebab eksternal antara lain karena dosen yang kurang menarik dalam menyampaikan kuliah, kebiasaan teman-teman di kos yang juga jarang belajar, adanya hp sebagai alat komunikasi dengan teman ataupun pacar juga dapat menyebabkan malas belajar.

\section{Bentuk-bentuk perilaku malas belajar mahasiswa}

Berkaitan dengan keadaan subjek yang memiliki perilaku malas belajar, peneliti memperoleh informasi tentang bentuk-bentuk perilaku malas belajar, berikut ini penjelasan dari masing-masing subjek.

Mm : "Jika dirumah sudah banyak kegiatan dan tinggal capeknya, terus saya rasa dosennya tidak terlalu teliti dalam masalah absensi, saya sering minta tolong teman untuk mengabsenkan. Dikampus dosen seringkali memakai metode ceramah, kalau temanya menarik saya semangat banget mengikuti jalannya diskusi, tetapi kalau membosankan ya bikin ngantuk aja. Kalau ada tugas membuat makalah saya paling malas mengerjakan, kadang saya meminta teman untuk mengerjakan makalah saya. Di kampus saya sering menjumpai mahasiswa yang malas belajar, rata-rata juga begitu kok, teman-teman saya juga sering bercerita sering malas sekali pergi ke kampus".

Fl : "Ketika rasa malas belajar muncul, waktu kuliah saya biasanya memilih tempat duduk paling belakang mbak, terus kalau dosennya ceramah, rasanya seperti di ninabobokkan gitu, saya pernah juga sampai ketiduran. Saya itu paling malas membaca, jadi juga jarang banget ke perpustakaan. Kalau ke perpustakaan paling saya 
menikmati fasilitas internetan gratis, jarang gitu pinjam buku, lha wong saya tidak mempunyai hobi membaca kok".

Me : "Ketika saya malas untuk mengikuti kuliah, kadang saya asik dudukduduk diparkiran, atau duduk-duduk dibawah pohon. Terus kalau lagi bete gitu mbak, ya di kosan aja, tapi ngak masuk kuliah. Temantemanku ada juga yang malas, sering tidak masuk kuliah, terus kalau ada tugas kuliah kadang malah absen untuk menghindari tugas. Yang rajin belajar ada juga tapi yang malas belajar juga banyak".

St $\quad$ : Ketika di dalam kelas, saya mencari tempat duduk yang strategis, buat ngilangin jenuh ya smsan sama pacar, sama teman. Dan beberapa kali saya juga menerima telpon ketika dalam kelas, nah kesempatan itu ada jika pada waktu diskusi saya duduk paling belakang, yang aman dari pantauan dosen mbak. Saya senang membaca novel, kalau buku kuliah sih jarang dibaca, dan kalaupun harus belajar biasanya mendekati ujian akhir semester gitu baru mau belajar".

Dari hasil wawancara dengan subjek 1, yang terkait dengan bentuk-bentuk perilaku malas belajar mahasiswa adalah subjek sering meminta tolong temannya untuk mengisi absennya jika dosen tidak teliti dalam masalah absensi, subjek sering merasa mengantuk dikelas, kadang meminta teman untuk mengerjakan tugas membuat makalah. Hasil wawancara dengan subjek 2, yang terkait dengan bentuk-bentuk perilaku malas belajar mahasiswa adalah subjek senang memilih bangku kuliah yang paling belakang, pernah juga sampai tertidur dikelas ketika dosennya ceramah, subjek juga jarang sekali ke perpustakaan, dan tidak hobi membaca. Dari hasil wawancara dengan subjek 3, yang terkait dengan bentuk-bentuk perilaku malas belajar mahasiswa adalah subjek kadang asyik duduk-duduk di sekitar lingkungan kampus dan tidak mengikuti kuliah walaupun dosennya ada.Hasil wawancara dengan subjek 4, yang terkait dengan bentuk-bentuk perilaku malas belajar mahasiswa adalah subjek sering bermain hp saat jam kuliah, sering sms dan beberapa kali menerima telpon ketika di dalam kelas. Dari wawancara peneliti dengan subjek bisa diambil kesimpulan bahwa di kampus juga terdapat mahasiwa yang malas belajar, perilaku malas belajar mahasiswa juga terlihat di lingkungan kampus. Bentuk-bentuk perilaku malas belajar mahasiswa juga beraneka ragam antara mahasiswa satu dengan mahasiswa yang lain. 
Dari contoh permasalahan yang diteliti oleh Rina Dwi Wahyuni (2010) tentang Perilaku Malas Belajar Mahasiswa di Lingkungan Kampus STAIN Tulungagung beserta teori yang dipaparkan diatas dapat disimpulkan bahwa Mahasiswa memiliki latar belakang yang beraneka ragam, memiliki kebiasaan, cara pikir, dan tingkah laku yang berbeda-beda. faktor - faktor yang menyebakan mahasiswa mempunyai perilaku malas belajar salah satunya yaitu lingkungan (faktor eksternal). lingkungan memiliki pengaruh terhadap perilaku seseorang. Terutama berkaitan dengan perilaku malas belajar, seseorang yang memiliki sedikit motivasi belajar akan mudah terpengaruh dengan temannya sehingga timbul rasa malas belajar, dosen yang kurang menarik dalam menyampaikan kuliah, kebiasaan teman-teman di kos yang juga jarang belajar, adanya hp sebagai alat komunikasi dengan teman ataupun pacar juga dapat menyebabkan malas belajar. "Faktor eksternal merupakan faktor yang datang dari luar individu, yang merupakan pengalamanpengalaman, alam sekitar, pendidikan dan sebagainya". Oleh karena itu, pengaruh lingkungan merupakan salah satu faktor penyebab terjadinya perilaku malas belajar. Selain itu ada faktor internal. Sebab internal antara lain karena lelah, kecapean, tidak adanya motivasi belajar.

Sedangkan menurut pengamatan peneliti bentuk - bentuk perilaku malas belajar mahasiswa yang ditunjukkan di lingkungan kampus meliputi: tidak masuk kuliah (sering absen), sering datang terlambat. tidak mengerjakan tugas kuliah, tidak memperhatikan dosen yang sedang mengajar (asik berbicara dengan teman ketika dosen menyampaikan pelajaran), tidur atau mengantuk didalam kelas saat proses pembelajaran, bermain $\mathrm{hp} \mathrm{di}$ saat jam kuliah (sms dan menerima telpon saat jam pelajaran), jika ada tugas kelompok tidak mau mengerjakan dan bergantung pada teman yang lain, belum belajar atau melakukan persiapan ketika akan presentasi makalah, dan lain sebagainya. Lingkungan ternyata memiliki pengaruh yang cukup berarti. Terutama berkaitan dengan perilaku malas belajar, seseorang yang memiliki sedikit motivasi belajar akan mudah terpengaruh dengan temannya sehingga timbul rasa malas belajar. Dari berbagai teori yang ada bahwa lingkungan memiliki pengaruh terhadap sikap dan perilaku seseorang. "Malas adalah kebiasaan yang dipelajari dan dibentuk oleh kondisi lingkungan dan orang-orang sekitarnya". Sifat malas ini akibat ketidakmampuan mengelola waktu dan tiadanya disiplin diri, bukan sifat bawaan. Oleh sebab itu, agar sifat malas ini tidak terbentuk, perlu dibiasakan untuk menghargai waktu dan disiplin. Malas belajar dapat timbul baik dalam 
diri mahasiswa itu sendiri maupun dari luar diri mahasiswa. Dari dalam diri sendiri misalnya rasa bosan dan kurangnya motivasi diri. Dari luar misalnya dosen kurang kreatif dalam menyampaikan materi kuliah, sehingga terkesan monoton dan tidak menarik.

Hal ini sejalan dengan teori yang disampaikan oleh Teori Bronfrenbrenner yang dipaparkan oleh Sarlito Wirawan Sarwono (2003) yang berparadigma lingkungan (ekologi) ini menyatakan bahwa perilaku seseorang (termasuk perilaku malas belajar pada mahasiswa) tidak berdiri sendiri, melainkan merupakan dampak dari interaksi orang yang bersangkutan dengan lingkungan di luarnya".

Dari berbagai pemaparan diatas dapat diambil kesimpulan bahwa lingkungan kampus yang merupakan tempat mahasiswa berinteraksi dengan individu yang lain dapat mempengaruhi perilaku malas belajar mahasiswa. Faktor lain yang menyebabkan kemalasan belajar dikalangan mahasiswa yaitu mereka tidak lagi percaya diri dengan potensi dan kemampuan berpikir. Oleh karena itu mahasiswa harus dapat berubah menjadi lebih baik, berprestasi, kreatif, dan produktif. Karena mahasiswa memiliki peran untuk menyebarkan ilmu, turut serta dalam memberantas kebodohan, dan mahasiswa mampu menyuarakan aspirasi masyarakat sehingga terciptalah perubahan di masyarakat dan bangsa.

\section{KESIMPULAN DAN SARAN}

\section{Kesimpulan}

1. Faktor-faktor penyebab malas belajar

Mahasiswa memiliki latar belakang yang beraneka ragam, memiliki kebiasaan, cara pikir, dan tingkah laku yang berbeda-beda. Dari wawancara peneliti dengan subjek bisa diambil kesimpulan bahwa penyebab malas belajar mahasiswa muncul dari dalam diri mahasiswa itu sendiri (internal) dan dari luar (eksternal). Sebab internal antara lain karena lelah, kecapean, tidak adanya motivasi belajar. Sebab eksternal antara lain karena dosen yang kurang menarik dalam menyampaikan kuliah, kebiasaan teman-teman di kos yang juga jarang belajar, adanya hp sebagai alat komunikasi dengan teman ataupun pacar juga dapat menyebabkan malas belajar.

2. Bentuk-bentuk perilaku malas belajar mahasiswa di lingkungan kampus

Perilaku malas belajar mahasiswa ditunjukkan dalam berbagai bentuk, dan menurut pengamatan peneliti, bentuk-bentuk malas belajar di lingkungan kampus meliputi: 
tidak masuk kuliah (sering absen), sering datang terlambat. tidak mengerjakan tugas kuliah, tidak memperhatikan dosen yang sedang mengajar (asik berbicara dengan teman ketika dosen menyampaikan pelajaran), tidur atau mengantuk didalam kelas saat proses pembelajaran, bermain hp di saat jam kuliah (sms dan menerima telpon saat jam pelajaran), jika ada tugas kelompok tidak mau mengerjakan dan bergantung pada teman yang lain, belum belajar atau melakukan persiapan ketika akan presentasi makalah, dan lain sebagainya. Lingkungan ternyata memiliki pengaruh yang cukup berarti. Terutama berkaitan dengan perilaku malas belajar, seseorang yang memiliki sedikit motivasi belajar akan mudah terpengaruh dengan temannya sehingga timbul rasa malas belajar. Dari berbagai teori yang ada bahwa lingkungan memiliki pengaruh terhadap sikap dan perilaku seseorang.

\section{Saran}

1. Bagi Universitas Trunojoyo Madura. Diharapkan lembaga memberikan perhatian dan bimbingan yang cukup berarti bagi perkembangan belajar mahasiswa dengan memanfaatkan bimbingan dan konseling sebagaimana mestinya.

2. Bagi mahasiswa

Bagi mahasiswa, agar menjadikan pengetahuan dan pemahaman untuk memotivasi diri agar lebih semangat dan lebih giat dalam belajar.

3. Bagi peneliti selanjutnya

Meneliti manusia yang berinteraksi dengan lingkungan sekitarnya bukanlah hal yang mudah, perlu pemahaman yang lebih mendalam dan kecermatan. Untuk itu bagi peneliti selanjutnya agar meningkatkan kualitas penelitiannya, terutama pengenalan kepada subjek yang lebih mendalam tentang peribadi dan tingkah lakunya. Sehingga hasilnya lebih baik lagi dan dapat dijadikan sebagai acuan serta pedoman dalam meningkatkan kualitas pendidikan yang lebih kompeten.

\section{DAFTAR PUSTAKA}

Burhanuddin Salam. 2004. Cara Belajar Yang Sukses di Perguruan Tinggi. Jakarta: Rineka Cipta.

Ermiza. 2013. Faktor-faktor yang Berhubungan dengan Motivasi Belajar. Jurnal Maternity and Neonatal,2.3: 18-190.

Lexy J. Moleong. 2008. Metodologi Penelitian Kualitatif. Bandung: Remaja Rosdakarya. 
Maulidia, Rahmah. Problem Malas Belajar Pada Remaja. Jurnal Tsaqafah,3.2: 129-134

Muiz. 2008. Tipologi Mahasiswa, dalam http://el-muis87.blogspot.com/2009/01/tipologimahasiswa.html, diakses 4 Mei 2010

Paryati Sudarman. 2004. Belajar Efektif di Perguruan Tinggi. Bandung: Simbiosa Rekatama Media.

Satria Anandita. 2010. Fakultas Kebebasan, dalam http://satria.anandita.net/fakultaskebebasan.str, diakses 1 April 2010

Veithzal Rivai. 2006. Kepemimpinan dan Perilaku Organisasi. Jakarta: PT. Grafindo Persada. 